American Journal of Applied Sciences 4 (8): 543-546, 2007

ISSN 1546-9239

(C) 2007 Science Publications

\title{
Comparative Characterization of Clinker's Microstructure at Different Temperature Zone during Cement Production
}

\author{
${ }^{1}$ Mohd Sobri Idris, ${ }^{2}$ Khairul Nizar Ismail, ${ }^{1}$ Shamsul Baharin Jamaludin, \\ ${ }^{1}$ Che Mohd Ruzaidi Ghazali and ${ }^{1}$ Kamarudin Hussin \\ ${ }^{1}$ School of Materials Engineering and ${ }^{2}$ School of Environmental Engineering, \\ University Malaysia Perlis (UNIMAP), PO Box 17, Pejabat Pos Kangar, 01007 \\ Kangar, Perlis, Malaysia
}

\begin{abstract}
Temperature is an important parameter for transformation of minerals in clinker during cement productions. It influences the formation of alite from belite during calcinations and clinkering processes. The result of microstructure shows that the formation of belite minerals started at temperature nearly $1200^{\circ} \mathrm{C}$ which is at calcinations zone temperature, followed by formation of $\alpha$ belite at higher temperature (around $1300^{\circ} \mathrm{C}$ ), then formation of $\beta$-belite and finally, with the suitable conditions it will form alite minerals. The differences between minerals are identified physically using scanning electron microscope (SEM).
\end{abstract}

Keywords: Clinker, microstructure

\section{INTRODUCTION}

Portland cement is made by heating a mixture of limestone and clay, or other materials of similar composition to a temperature of about $1450^{\circ} \mathrm{C}$. Partial fusion occurs and nodules of clinker are produced. The clinker is mixed with a few per cent of calcium sulphates and finely ground, to produce cement ${ }^{[1]}$. Temperature around $1450^{\circ} \mathrm{C}$ is required during production of cement in order to achieve suitable condition for formation of $\mathrm{Ca}_{3} \cdot \mathrm{SiO}_{5}$ or known as alite's minerals. Alite's minerals are a major content required in the Portland cement because it contributes to instant hydration and responsible to early stage of concrete hardening. Percentage of alite should be achieving minimum $70 \%$ of minerals content in Portland cement in order to exceed international standards and requirements.

Alite minerals have formed from the reaction of $\mathrm{CaO}$ and $\mathrm{SiO}_{2}$, within suitable condition and equilibrium reaction of the system $\mathrm{SiO} 2-\mathrm{CaO}-\mathrm{Al}_{2} \mathrm{O}_{3}$ during clinkering temperature which is around $1450^{\circ} \mathrm{C}^{[2]}$. Alite $\left(\mathrm{Ca}_{3} \mathrm{SiO}_{5}\right)$, forms the bulk of a clinker (40-70\%, by mass) with crystal sizes up to about $150 \mu \mathrm{m}$. Alite generally displays a hexagonal crystal habit in cross section, with crystal shape ranging from euhedral (clearly-defined crystal faces) or to subhedral (poorly-defined crystal faces), to anhedral (no crystal faces). Minor oxide contents may range from about $3 \%$ to $4 \%$ by mass. Alite reacts rapidly with water and responsible for much of the early-age (28 days) strength development $^{[3]}$.

Formation of alite as major contents of minerals in clinker was studied in this research in order to observe the evolution of microstructure during burning. This study has been carried out using various samples taken from kiln at different places represented as different zone of reactions. Morphology characterization was investigated under scanning electron microscope (SEM) and optical microscope to identify mineral phases present at every stage of reaction. Quantitative analysis was used to identify chemical content present in samples and mineral contents were calculated by using Bogue calculation. X-ray diffraction was used to confirm existing phases in samples according to Emmanualson $^{[4]}$.

\section{MATERIALS AND METHODS}

The clinker samples were supplied by Cement Industries of Malaysia Limited (CIMA Limited) located at Bukit Keteri, Perlis, Malaysia. The samples were taken from a various place in kiln that have different section of temperature zone during production of

Corresponding Author: $\quad$ Mohd Sobri Idris, School of Materials Engineering, University Malaysia Perlis (UNIMAP), PO Box 17, Pejabat Pos Kangar, 01007, Kangar, Perlis, Malaysia, Tel: +604-9798648, Fax: +604-9798178 
cement. The samples were taken from four sections, which are section A (15 meter from end of kiln), section B (10 meter from end of kiln), section C (5 meter from end of kiln) and section $\mathrm{D}$ (at the end of kiln). Each sample was divided into three for different analysis. Samples were prepared according to ASTM procedure before investigated under optical microscope and SEM JEOL 6460 LA with $12 \mathrm{kV}$ acceleration volt. Samples for microstructure analysis need to be molded in resin and polished down to $0.05 \mu \mathrm{m}$. Samples were also etched with nital for 20 s before analyzed using optical microscope and SEM.

\section{RESULTS AND DISCUSSION}

Figure 1 shows the microstructure images for four samples analyzed using optical microscope and Fig. 2 shows the microstructure images under scanning electron microscope (SEM). Figure 1a and $2 \mathrm{a}$ represent samples from section A. Figure $1 \mathrm{~b}$ and $2 \mathrm{~b}$ represent samples from section B. Furthermore, Fig. 1c and 2c represent samples from section C, finally Fig. $1 \mathrm{~d}$ and $2 \mathrm{~d}$ represent samples from Section D.
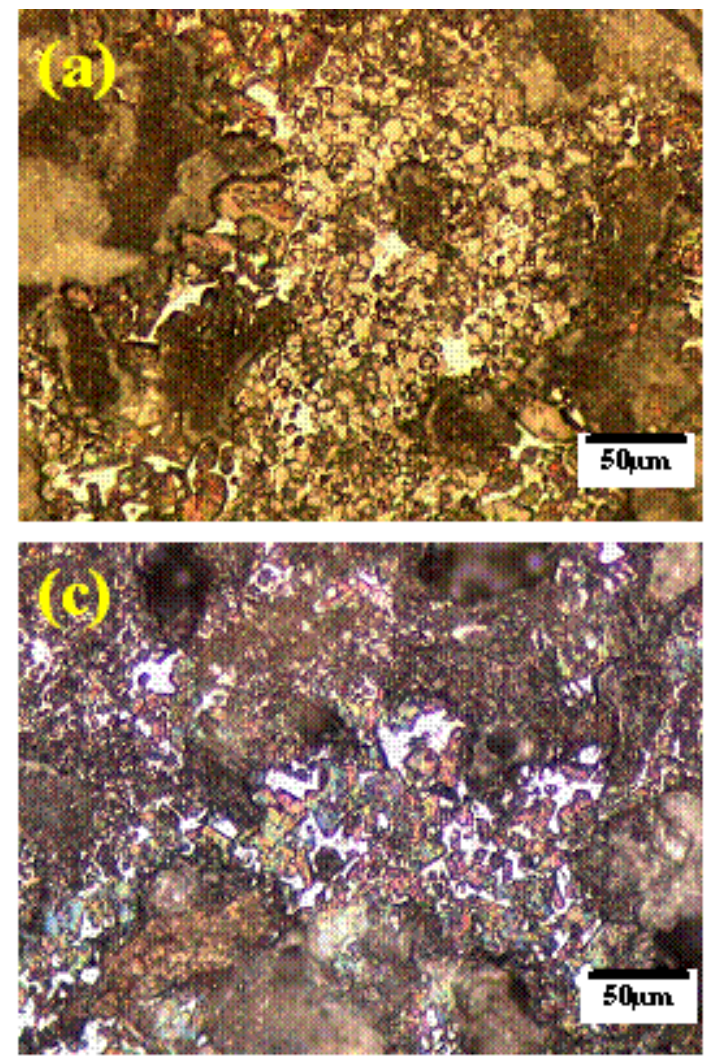

Figure 1a and $2 \mathrm{a}$ show a lot of belite content in this sample and its grain size of in between $10 \mu \mathrm{m}$ until $20 \mu \mathrm{m}$. It has a few alite with smaller grain size relatively appeared in between belite contents. This finding is similar with Hills (2001), she reported that within $1200^{\circ} \mathrm{C}$ to $1350^{\circ} \mathrm{C}$, liquid phases started to form and at this stage, belite reacted with free lime to form initial phase of alite. This microstructure indicates a few alite content present in this sample, which means this stage probably at temperature around $1250^{\circ} \mathrm{C}$. According to $\mathrm{Hills}^{[4]}$, that sample may be at the end of calcinations zone and just started a clinkering zone $^{[4]}$.

Eventually, Fig. 1b and $2 \mathrm{~b}$ represented sample B showing that, the alite minerals content increasingly with belite minerals phase contribution. This condition showed that the clinkering reaction had started when belite reacted and converted to alite minerals. However, this reaction may be at early stage because a few alite mineral phases are initially formed in between belite mineral phases. Undoubtedly, the sizes of belite minerals phase were constant and did not changed except at the edge of alite phases.
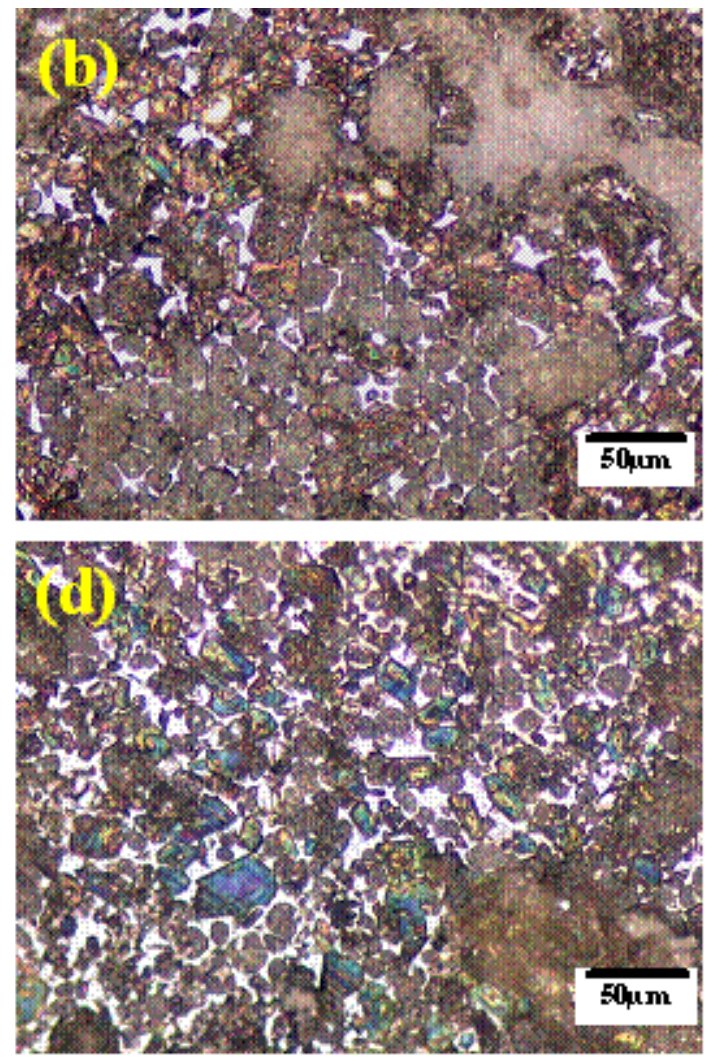

Fig. 1: Microstructure of four clinker samples with magnification 100X using optical microscope 

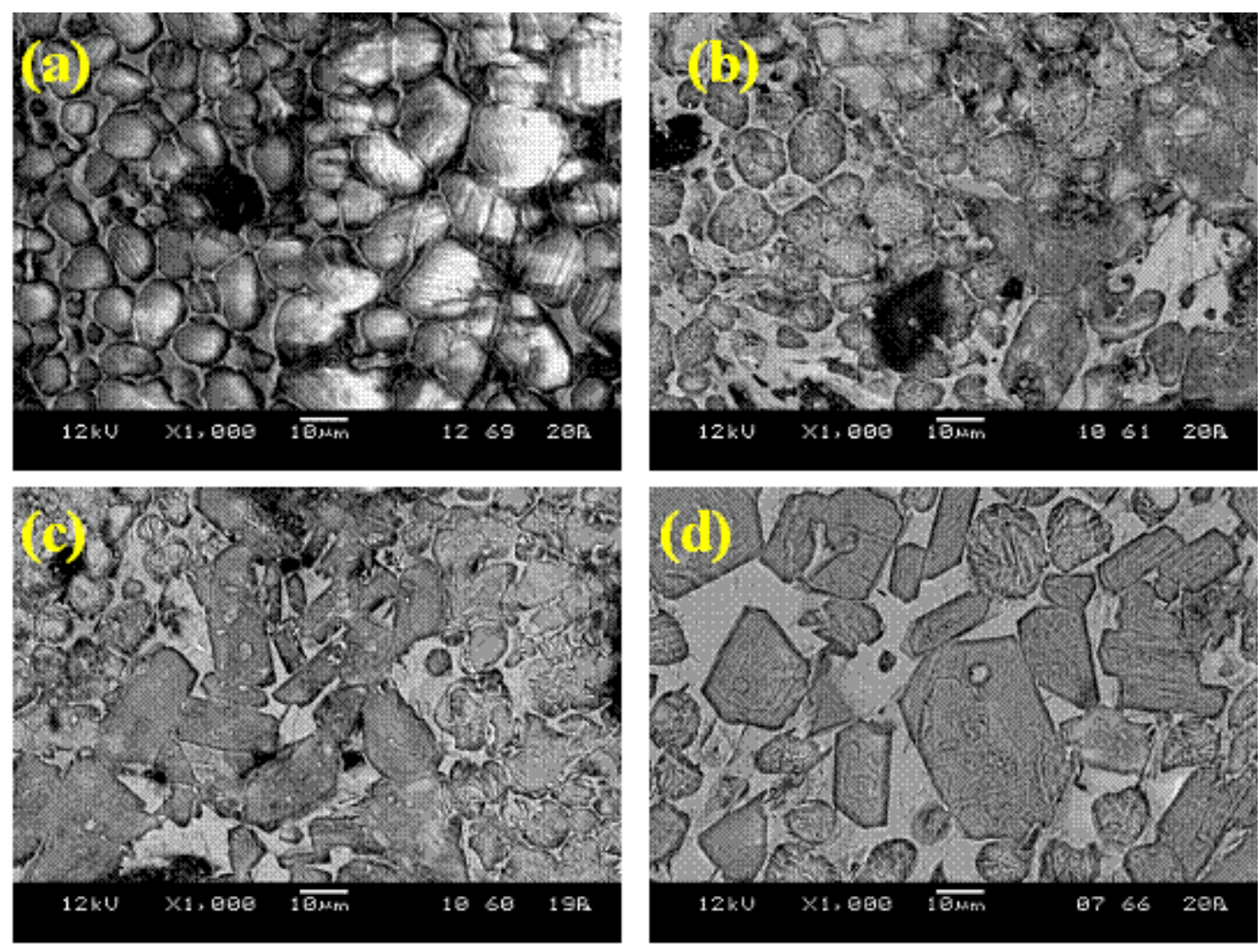

Fig. 2: Microstructure of four clinker samples with 1000X magnification using scanning electron microscope

Figure $1 \mathrm{c}$ and $2 \mathrm{c}$ show microstructure for sample C. It has a great changes identified from belite minerals that transformed to alite minerals phase. It can be observed that the size of belite minerals certainly relatively smaller than the size of alite minerals. At this stage during clinkering zone, phase transformation has increased rapidly and as a result, the image showed that the transformation already occurs in between region that have cluster of belite around the void, while in the centre of that cluster for instance is having phase transformation from belite to alite minerals. Furthermore, it can be seen clearly at the magnification $500 \mathrm{X}$, that segment showed alite minerals have formed in the centre of belite cluster, then at higher magnification (1000X) it was proved the transformation has occurred. This transformation is expected to be occurred aggressively and the amount of belite crystal has been reduced moderately ${ }^{[4]}$. On the other hand, alite minerals rose gradually in size and amount. These reactions probably occur between temperatures of $1350^{\circ} \mathrm{C}$ until $1450^{\circ} \mathrm{C}$.

Figure 1d and 2d show micrograph for sample D indicated that clinkering reaction occurs completely.
The microstructure shows the size of alite minerals phase slightly bigger than belite minerals around it. The size and amount of belite minerals have been reduced dramatically. The size of belite minerals is identified in between $5 \mu \mathrm{m}$ until $10 \mu \mathrm{m}$, whereas in Fig. $1 \mathrm{~b}$, the size is between $10 \mu \mathrm{m}$ until $20 \mu \mathrm{m}$. Admittedly, this stage is the end of clinkering process and the reaction already completed before it cooled down rapidly.

In general, Fig. 2 shows the comparison of mineral phases and it could be the evidence for the difference phases present in four samples. A various size of belite from the small size to maximum size approximately $20 \mu \mathrm{m}$ observed in the Fig. 2a. In contrast, Fig. 2b shows a different morphology of belite mineral phases. Probably, the morphology of belite mineral phases have changed due to transformation of belite to $\alpha$-belite or $\beta$ belite.

Furthermore, Fig. 2c shows the alite mineral phases occur in between region that have cluster of belite. This micrograph also shows the shape of alite mineral is incompletely obtained. The size of belite respectively small than occurs in Fig. 2a and 2b. Figure 2d shows the mineral phases of clinker in the sample reached 
completely clinkering process. It shows that alite mineral phase completely formed and showing hexagonal crystal habit and reached maximum size approximately $30 \mu \mathrm{m}$.

Scanning electron micrograph clearly shows the chronology of mineral phases transformation at different stage of reaction during clinkering process.

\section{CONCLUSION}

Transformation of mineral phases is found affected by different temperature during cement production. The formation of belite and alite phases in cement clinker can be clearly observed under scanning electron microscope. The microstructure study indicates the formation of belite at temperature approximately $1200^{\circ} \mathrm{C}$, followed by transformation to $\alpha$-belite, $\beta$-belite and finally changed to alite at high temperature within suitable condition.

\section{ACKNOWLEDGEMENTS}

We would like to acknowledge CIMA Limited, Malaysia for the contribution of clinker samples and KUKUM for providing the Short-Term Grant to support this project.

\section{REFERENCES}

1. Tylor H.F.W., 1997. Cement Chemistry, Thomas Telford Publishing, London, pp: $12-28$.

2. Stutzman, P, 2004. Scanning Electron Microscopy Imaging Of Hydraulic Cement Microstructure, Cement \& Concrete Composites 26: 957- 966.

3. Idris, M.S., 2006. Kajian Pencirian Mikrostruktur Klinker Semasa Pengeluaran Simen, Unpublished MSc Thesis, School of Materials Engineering, Northern Malaysia University College of Engineering. 2006

4. Hills, L.M, 2000. Clinker Formation and the Value of Microscopy, Proceeding of Twenty-Second International Conference on Cement Microscopy, Montreal, pp: $1-12$. 